\title{
THE YOUNG ENTREPRENEURS OF EUROPE AND THE ROLE OF INTERNATIONAL MOBILITY
}

\author{
Monica Roman $^{1 *}$ and Dorel Mihai Paraschiv ${ }^{2}$ \\ ${ }^{1)}$ Bucharest University of Economic Studies, Bucharest, Romania, \\ IZA Bonn, Germany and CELSI Bratislava, Slovakia \\ ${ }^{2)}$ Bucharest University of Economic Studies, Bucharest, Romania
}

\begin{abstract}
Please cite this article as:
Roman, M. and Paraschiv, D.M., 2019. The Young Entrepreneurs of Europe and the Role of International Mobility. Amfiteatru Economic, 21(Special No. 13), pp. 763-777.
\end{abstract}

\section{Article History}

Received: 5 August 2019

Revised: 20 September 2019

Accepted: 4 October 2019

\section{DOI: 10.24818/EA/2019/S13/763}

\begin{abstract}
The Single European Market and the warranty of freedom of movement of goods and people within the European Union has made an impact in the share of European youth travelling internationally. This phenomenon has brought countless advantages including increased economic performance on the labor market, development of entrepreneurial actions and even personal growth.

This paper estimates the impact of international mobility in Europe on youth entrepreneurship, after the individual's returning in the country of origin. The data source for this study is a European survey launched within the Horizon 2020 project MOVE "Mapping mobility - pathways, institutions and structural effects of youth mobility in Europe". Using Prosperity Score Matching on a generous sample providing data on both mobile and non-mobile respondents, we prove that people have double chances of becoming entrepreneurs if they had an intra-European mobility experience. Even though mobility has been shown to have statistically significant benefits, it only affected the entrepreneurship of European youth in a conservative way explained by the factors that encourage the youth to travel abroad.
\end{abstract}

Keywords: Youth intra-European Mobility, Young Entrepreneurs, Propensity Score Matching, Europe

JEL Classification: J13, J61, L26

\footnotetext{
* Corresponding author, Monica Roman - monica.roman@ csie.ase.ro
} 


\section{Introduction}

In the context of the increasing youth unemployment rate in Europe, the policy makers consider self-employment and entrepreneurship to be not only a strategy for economic development and promoting innovation, but a way to develop job creation and raise employment among youth. Unfortunately, entrepreneurship is not common among young people and the self-employment rate in Europe is less than $5 \%$ among youth and $14 \%$ in total population (Eurostat, 2019). Some new interesting trends have emerged in recent years: in some countries in Eastern Europe, such as Romania, the self-employment rate of young people increased, as it has for the working-age population, while in Germany and Luxembourg there were registered some of the lowest values in Europe; in Spain the youth self-employment rate has increased to almost $7 \%$. Spain also has one of the highest youth unemployment rates in Europe which may have stimulated many young people to go into self-employment (OECD/European Union, 2017).

Although youth is the most mobile demographic category (Constant, Nottmeyer and Zimmermann, 2013), the role of international mobility in the particular case of young entrepreneurs is not entirely explored. The current literature on the determinants of entrepreneurship mostly deals with adult or total migrant population (Roman, 2019; Lofstrom and Wang, 2019). The paper contributes to the entrepreneurship literature by looking at international mobility, as a specific factor for boosting youth self-employment. Therefore, this research aims to fill a gap and explores the nexus mobility, entrepreneurship, and youth. The main purpose of the study is to identify the potential impact of international mobility on youth successful entrepreneurship in Europe and to quantify the magnitude of this impact.

We use primary data collected in the project "Pathways, Institutions, and Structural Effects of Youth Mobility in Europe" (MOVE) project, financed by the Horizon 2020 Program between 2015 and 2018. MOVE aimed at contributing to the research on the conditions of young people mobility in Europe by identification ways of good practice and thus fostering sustainable development and wellbeing (Navarrete et al., 2017). The surveys was conducted among young people in order to explore their mindsets, experiences and motivations regarding mobility, and barriers or reasons that hold non-mobile young participants in their countries. The data set includes a sample of 5499 young respondents and covers six countries: Germany, Norway, Spain, Romania, Hungary and Luxembourg.

It should be noticed that most of the related existing literature refers to migration and its interaction with entrepreneurship, and the concept of mobility is less applied. The two concepts, migration and mobility, are used in many cases interchangeably, since there is a certain overlap between them. The concept of mobility differs from migration in at least two dimensions: spatial and temporal. Mobility covers intra-European cross border movement of EU citizens and has a rather short term, temporary character. European mobiles are therefore more difficult to be captured in official statistical data, since their movement is irregular, short term. Unlike most of the existing literature that regards migrants' entrepreneurship in destination countries (Baycan-Levent and Nijkamp, 2009; Roman, 2019) our paper considers a more fluid mobility process and tackles entrepreneurial activities after the individual's return to their home country. Therefore, the paper contributes to the growing literature on return migration (Roman and Goschin, 2012). However, the main contribution of the paper is that it is focused on less studied mobile youth, defined as individuals aged between 18 and 29 years who have spent at least two 
weeks abroad for other purposes than tourism or family reasons. The dataset includes both mobile and non-mobile respondents suitable for our methodological approach that mainly relies on propensity score matching, a semi-parametric method with increasing popularity in the field of impact studies. Worth also mentioning that our research considers entrepreneurship as the current occupational status, less tackled in the literature, rather than as the intention of being entrepreneur. A number of papers refers to the intensity of the entrepreneurial intentions among youth and students in particular (Nabi and Liñán, 2011; Díaz-García and Jiménez-Moreno, 2010; Popescu et al., 2016). In a recent overarching meta-analysis, Liñán and Fayolle (2015) list a number of determinants affecting the intentions of becoming entrepreneur; however, migration or mobility were not included as potential factors, confirming the need for further research in this area.

The rest of the papers is structured as follows: the first section reviews the relevant studies, section 2 presents the methodology applied, section 3 describes the data set and the variables, while section 4 present the results. Finally, the last section concludes the paper.

\section{Literature review}

Insight in the relationship between entrepreneurship determinants and economic development across countries is important not only from an academic perspective, but also for policymakers and business environment. Not only self-employment creates new jobs, increases productivity, but also contributes to economic growth, boosting innovation and competitiveness. In the context of sustainable development, entrepreneurship is becoming a popular research topic, and the growing literature emphasizes the increasing role of "sustainable entrepreneurship" (Kardos, 2012). This is an "all-inclusive concept addressing the contribution of entrepreneurial activities to solving societal and environmental problems, to sustainable development in a more comprehensive way" (Kardos, 2012). Sustainable entrepreneurship is described with several features such as social responsibility, competitiveness, progressiveness, knowledge creation and usage, innovativeness, dynamism and seeks for business benefits creating social value in a global environment (Krisciunas and Greblikaite, 2007).

The environment and institutions shaping the economy affect the dynamics of the entrepreneurship within any given country. As reported by Acs and co-authors, institutions directly influence entrepreneurship through a number of channels such as the quality of governance, access to capital and other resources (Acs et al., 2008). The access to knowledge gathered through an international mobility experience is also shaped by the institutional context and could impact self-employment, as we attempt to prove in the current paper.

Following a dynamic approach that distinguishes between solo self-employed and ambitious innovative entrepreneurs, Wennekers et al. proved that many advanced economies show a revival at both extremes at the entrepreneurial spectrum (Wennekers et al., 2010). Considering more complex measures, such as the Complex Entrepreneurship Context Index which is positively related to development, Virgill (2009) proved that a Ushaped relationship no longer stands and an $\mathrm{S}$ shape is more appropriate. These results suggest that it is no longer enough to look at entrepreneurship in a static approach, as various characteristics of the business across its lifecycle impact economies differently. In both cases mentioned above, a dynamic approach of the entrepreneurial activity is needed for producing relevant results. According to Reynolds, the dynamic perspective implies 
considering "early-stage entrepreneurial activity" (Reynolds et al., 2005). This notion includes the activities of both nascent entrepreneurs and owners of new businesses.

Even if self-employment has become a key policy issue, the literature on entrepreneurship and on youth entrepreneurship in particular is not without limitations. In all societies youth is a key factor for progress and innovation, becoming the engine of sustainable entrepreneurship; youth entrepreneurial behavior needs to be understood in order to be better supported and encouraged. The growing number of papers supports this goal.

Youth entrepreneurs have different reasons when starting their businesses and these reasons vary depending on the economic development of the different countries. As reported by OECD, in developed countries such as the UK, the youth are motivated primarily by desires for independence and flexibility and not necessarily by economic reasons (OECD, 2001).Youth in developing countries go into self-employment out of economic necessity, but also for the ,need to survive, or out of failure to find productive use of their energy in other avenues" (Chigunta, 2002).

Studying the determinants of entrepreneurship, many studies identified a strong need to complement the existing analysis, which focuses on the psychological and nonpsychological characteristics of the individual entrepreneur with the analysis of environmental characteristics such as: the availability of resources and competition, as well as the conditions of the institutions that govern economic activity (Cuervo, 2005). Other than demographic variables, the set of variables used for explaining entrepreneurship includes the perception of the respondents on administrative complexities, availability of financial support and risk tolerance (Grilo and Thurik, 2005).

Looking at Scandinavian countries, Dvouletý analyzes the role of administrative barriers on necessity and opportunity-driven entrepreneurship. Nikolaev et al. evaluate the robustness of 44 possible determinants of early- stage opportunity- motivated entrepreneurship and necessity- motivated entrepreneurship that are broadly classified in four groups: (1) economic variables, (2) formal institutions, (3) cultural values, and (4) legal geographical origins. The results suggest that institutional variables associated with the principles of economic freedom are most strongly correlated to entrepreneurship (Nikolaev et al., 2018). At the same time, the determinants of youth entrepreneurship are presented in various papers (Chigunta, 2002; Ojiaku et al., 2018; Kojo Oseifuah, 2010; Popescu \& Roman, 2018) that describe human capital related factors, such as financial literacy, education and vocational training.

Migration, as a global demographic phenomenon, impacts entrepreneurship in various ways: it could be a driver for entrepreneurship in destination countries, but it could also lead to entrepreneurial activities after migrants return home. International mobility is an increasing phenomenon among European youth, mostly after the creation of the Single European Market and the warranty of freedom of movement of goods and peoples within the European Union. Labor mobility and migration improve the functioning of the labor markets through the balancing of skill needs, labor-market shortages, and unemployment. Being internationally mobile has positive consequences on personal development and on economic performance on the labor market (Manafi et al., 2017; Roman and Paraschiv, 2019). However, in spite of its increasing relevance, the influence of mobility on the propensity of becoming a freelancer or entrepreneur is not much explored in the economic literature (Wahba, 2015). 
The nexus between migration and entrepreneurship has been primarly explored from the perspective of migrant entrepreneurs or self-employed migrants, as they are perceived as a vector for sustainable development (Naudé, Siegel and Marchand, 2017). When looking at migration as a determinant for entrepreneurship, a growing recent literature points out the issue of endogeneity, as the two variables could be simultaneously affected by common unobserved factors. Therefore, other authors examine the determinants of entrepreneurial behavior among return migrants in Morocco, controlling for the potential endogeneity of the migration duration. The main findings suggest that individual characteristics and conditions before migration matter for entrepreneurship (Hamdouch and Wahba, 2015). Using data from Egypt, it was proven that „,an overseas returnee is more likely to become an entrepreneur than a non-migrant (...), they accumulate savings and experience overseas that increase their chances of becoming entrepreneurs." (Wahba and Zenou, 2012).

More recently Brzozowski, Cucculelli and Surdej, investigate which factors influence the rise or decline of transnational entrepreneurial involvement with a home country. The results indicate that longer residence in Italy is associated with smaller propensity to become a transnational entrepreneur (Brzozowski, Cucculelli and Surdej, 2017). Other authors also use country specific socio-economic factors as determinant of self-employment The results of the binominal logit regression show that the Central European migrants exhibit different selfemployment propensity than migrants from former Yugoslavia, Russian and Kazakhstan, Turkey and Italy (Szarucki, Brzozowski, and Stankevičienè, 2016).

\section{Methodological approach}

The study primarily relies on a quasi-experimental approach in which the mobility experience is associated to a treatment applied to youth population in the six European countries. Matching is an intuitive procedure widely applied in the program and policy impact evaluation, but also in other fields, such as health and education. It implies simply selecting a group of non-treated individuals in order to make them resemble the treated ones in their observable characteristics, except for the fact of receiving the treatment (Rosenbaum and Rubin, 1983). If such a similarity is satisfactory, the outcome observed for the matched group approximates the counterfactual, and the effect of the intervention is estimated as the difference between the average outcomes of the two groups. According to Dehejia and Wahba (2002) when the relevant differences between any two units are captured in the observable pre-treatment covariates, which occurs when outcomes are independent of assignment to treatment conditional on pre-treatment covariates, matching methods can yield an unbiased estimate of the treatment impact. Moreover, matching is also considered an adequate strategy that could overcome the potential endogeneity between the treatment and the outcome variable.

Propensity score matching (PSM) (Rosenbaum and Rubin, 1983) is applied for identifying the existence of a potential impact of mobility on entrepreneurship and for measuring the magnitude if this impact. This is extremely relevant, as there are many other factors that influence entrepreneurship, as described in the previous section.

Our methodological strategy consists of two successive stages: firstly, we have tested the base model, using a logistic regression on entrepreneurship and including the mobility experience as determinant, alongside with other covariates suggested by the literature. In the second stage, PSM is applied to properly answer the initial research questions. 
Propensity score matching is a semi-parametric estimation in four main steps, briefly described in this section. The first step consists of estimating the propensity scores parametrically; the second step involves non-parametric comparison of these propensity scores by applying matching algorithms; step three involves checking the matching quality. Finally, the effect of the treatment is estimated. The effect is the average difference in expected outcome between treated and non-treated individuals. The two most frequent parameters for capturing the impact are the population average treatment effect (ATE) and the average treatment effect on the treated (ATT).

In the usual binary treatment case of treatment versus non-treatment, the propensity scores are usually estimated by either a probit or a logit model. In this research a binary logistic regression model was used for estimating the propensity scores. The binary dependent variable in the model is whether a person was internationally mobile or not. The regression model will predict the logit, that is, the natural log of the odds of having made one or the other decision. The binary dependent variable is the probability of a person to have an international mobility experience or to be an entrepreneur. We assume that the values of $y$ (binary variable) are coded 0 and 1 , with 1 expressing the realization of the event, so the model estimates the probability of this event to occur based on the values of the independent variables.

The general form of the model is:

$\ln \left(\frac{p}{1-p}\right)=\beta_{0}+\sum_{i=1}^{k} \beta_{i} x_{i}+\varepsilon$

where $p$ is: $p\left(y=1 \mid x_{1}, x_{2}, \ldots, x_{k}\right)$

The model is re-written in the following form:

$$
P\left(y=1 / x_{1}, x_{2}, \ldots x_{k}\right)=\frac{\exp \left(\beta_{0}+\beta_{1} x_{1}+\ldots \beta_{k} x_{k}\right)}{1+\exp \left(\beta_{0}+\beta_{1} x_{1}+\ldots \beta_{k} x_{k}\right)}
$$

After a simple calculation we obtain

$$
\exp \left(\beta_{0}\right)=\frac{P\left(y=1 / x_{1}=x_{2}=\ldots=x_{k}=0\right)}{P\left(y=0 / x_{1}=x_{2}=\ldots=x_{k}=0\right)}
$$

that is Odd Ratio, when all factors are set to zero.

For the $\beta_{i}$ coefficient we obtain:

$$
\exp \left(\beta_{i}\right)=\frac{P\left(y=1 / x_{i}=1, x_{j} 0 \text { for } j \neq i\right)}{1-P\left(y=1 / x_{i}=1, x_{j} 0 \text { for } j \neq i\right)} \times \frac{1}{O R_{\text {base }}}=\frac{O R_{i}=1, x_{j}=0}{O R_{\text {base }}}
$$

The $\beta_{i}$ coefficients are interpreted as the increase of logit (logarithm of OR) when $x_{i}$ increases by one (with other variables held constant).

For including the relevant variables in the model, we follow Caliendo and Kopeinig (2008), and we include variables which simultaneously affect both participation in treatment and outcome variable of interest. 
There are several matching methods proposed in the literature, and some of the most widely used are: the Nearest-Neighbour Matching (with or without caliper), the Radius Matching, the Stratification Matching and the Kernel Matching.

In the Nearest-Neighbour matching procedure, one or more persons from the comparison group are selected as matching partners for a treated individual that is closest in terms of propensity score. The method runs in two variants: matching "with replacement" and "without replacement". In the first case, an untreated individual can be used more than once as a match, whereas in the second case it is considered only once. The method implies minimizing the distance between the treated unit and the control units. It is worth mentioning that there is a large number of methods developed for computing such distances. The Euclidian distance with Mahalanobis transformation (also known as Mahalanobis distance) is widely applied (Weinberger and Saul, 2009).

The second applied matching method, the radius matching, is useful for the cases when the closest neighbor is at a considerable distance from the treated unit. A tolerance level is imposed on the maximum propensity score distance (calliper). Calipers are used for maximizing the acceptable distance and thereby avoiding poor matches and increasing the matching quality.

The third applied method, the Stratification method, is quite intuitive; the estimated propensity score is used to stratify the subjects into different strata, based on similar propensity scores. Each stratum consists of relatively the same number of subjects.

Finally, Kernel matching makes use of all the individuals in the sample, unlike the previous methods that employed a smaller number of units for matching. The method uses weighted averages of all individuals in the control group to construct the counterfactual outcome. Weights depend on the distance between each individual from the control group and the participant observation for which the counterfactual is estimated. Therefore, the kernel function assigns larger weight to observations close in terms of propensity score to a treated individual and smaller weight to more distant observations.

In this study all the four matching methods are applied for producing a strong result and as an instrument for comparing and validating the final results. For the purpose of a reliable matching, the pscore command in STATA was used (Becker and Ichino, 2002). The "common support" option was used for assessing the quality of the matching. Also, the balancing test was applied.

\section{Data and sample description}

The data used in this study resulted from the MOVE project large survey that focuses on cross-border geographic mobility of young people within Europe. A large number of variables were covered by the detailed questionnaire, including demographic characteristics, economic aspects, and perceptions on mobility, future plans and agency (Navarette et. al., 2017). Those respondents having multiple mobility experiences were given the possibility to describe each experience abroad and to declare the most relevant one. The mobile respondent, as captured by the survey data could therefore be regarded as a returnee, as the entrepreneurial activity was developed after ending the mobility experience.

The innovative approach of the MOVE project was that mobility experience was regarded according to its main purpose. Six different motives were identified as the main mobility 
purpose: work, study, volunteering, entrepreneurship, Vocational Education and Training and pupils' exchange (Hemming et al., 2019). "Mobility" was practically defined as having been abroad for a reason diff erent than tourism or visiting relatives longer, for at least 2 weeks. This "soft" concept of mobility was set to accommodate for all kinds of mobility types studied such as pupil's exchange (usually weeks), vocational training (in Germany 3 weeks), volunteering, etc. The sample distribution by mobility reasons show that $54 \%$ of the respondents have study related reasons for their international mobility, VET included, $24 \%$ have work related reasons, 5\% were mobile for volunteering, while $16 \%$ had other reasons for becoming mobile. Worth mentioning that only 18 respondents (counting for less than $1 \%$ of the sample) had the main mobility reason becoming an entrepreneur abroad, and their mobility was mainly supported through European programs such as ERASMUS+.

The employment status was recorded in detail in the survey and allows us to separate the entrepreneurs to different other occupations. The outcome variable was recorded as the "occupation of the respondent is entrepreneur or freelancer". Importantly, at the moment of the interview, the respondents were living in the country of origin and therefore the mobility experience was completed and finished. The distribution of the respondents by occupation shows that most of them are employed (49\%), a large share are still studying (39\%), as expected considering that analysis regards young individuals. A share of $14 \%$ are unemployed and a smaller proportion $(4.8 \%)$ are self-employed or freelancers. The share of entrepreneurs and freelancers in the sample is in line with the European average.

The variables involved in the models are age, gender, marital status, education and the knowledge of foreign languages, father's education, the size of the city of residence and the European region respondent lives in, but also the number of times the respondent was unemployed. Following the relevant previous results, we consider that these variables covering demographic and economic characteristics of the young entrepreneurs affect both the decision to become mobile and an entrepreneur. Similar characteristics affecting both the decision of being mobile and the entrepreneurial behavior are used in literature (i.e. Wahba and Zenou, 2012). These are detailed in the following section.

\section{Results and discussions}

The first step in calculating the propensity score is to define the treatment and control groups and the relevant outcome variable. The population of interest in this study is defined by those respondents who have declared entrepreneurship as their current occupation. Out of the 5499 respondents, 266 were at the moment of the survey entrepreneurs or freelancers $(4.8 \%)$ and out of these 144 were mobile (Table no. 1$)$.

The individual variables such as age and gender have similar values in the groups of mobile and non-mobile youth: the average age is 23.5 years in the case of non-mobile and 24.5 for the mobile ones, of which $46 \%$ are male. Interestingly, the mobile youth live in a larger share with a partner (44\%) compared to non-mobile ones $(39 \%)$. When looking at human capital, the mobile youth speak a foreign language (English, more specific) in a larger share as against non-mobile: $90 \%$ vs. $85 \%$. Education was also included in our models, as a strong predictor for both decisions to emigrate and becoming entrepreneur. Mobile respondents are better educated and $48 \%$ have higher education and $44.6 \%$ have secondary education. Among the stayers, only $38 \%$ have higher education, while $64.6 \%$ have secondary education. Parents' education was considered as a proxy for family background, 
as parents with higher education and better financial resources are more able to support the young members' decision to go abroad or to open a business.

Table no. 1: Descriptive statistics

\begin{tabular}{|c|c|c|c|c|c|}
\hline Variable & Obs. & Mean & Std. Dev. & Min & Max \\
\hline \multicolumn{6}{|l|}{ Non-mobile } \\
\hline Entrepreneur & 3431 & 0.0356 & 0.1852 & 0 & 1 \\
\hline Age & 3431 & 23.495 & 3.399 & 18 & 29 \\
\hline Male & 3431 & 0.463 & 0.499 & 0 & 1 \\
\hline Size of the place currently live in & 3431 & 4.113 & 1.584 & 1 & 9 \\
\hline Live with a partner & 3431 & 0.393 & 0.489 & 0 & 1 \\
\hline Speaks English & 3431 & 0.851 & 0.356 & 0 & 1 \\
\hline Has secondary education & 3431 & 0.646 & 0.478 & 0 & 1 \\
\hline Father's education & 3208 & 0.415 & 0.493 & 0 & 1 \\
\hline Number of times in unemployment & 3431 & 2.077 & 1.376 & 1 & 5 \\
\hline Eastern European & 3431 & 0.397 & 0.489 & 0 & 1 \\
\hline \multicolumn{6}{|l|}{ Mobile } \\
\hline Entrepreneur & 2068 & 0.070 & 0.255 & 0 & 1 \\
\hline Age & 2068 & 24.485 & 3.154 & 18 & 29 \\
\hline Male & 2068 & 0.472 & 0.499 & 0 & 1 \\
\hline Size of the place currently live in & 2068 & 4.238 & 1.641 & 1 & 9 \\
\hline Live with a partner & 2068 & 0.440 & 0.496 & 0 & 1 \\
\hline Speaks English & 2068 & 0.897 & 0.303 & 0 & 1 \\
\hline Has secondary education & 2068 & 0.446 & 0.497 & 0 & 1 \\
\hline Father's education & 1952 & 0.372 & 0.483 & 0 & 1 \\
\hline Number of times in unemployment & 2068 & 2.235 & 1.433 & 1 & 5 \\
\hline Eastern European & 2068 & 0.287 & 0.453 & 0 & 1 \\
\hline \multicolumn{6}{|l|}{ Total sample } \\
\hline Entrepreneur & 5499 & 0.048 & 0.215 & 0 & 1 \\
\hline Age & 5499 & 23.814 & 3.349 & 18 & 29 \\
\hline Male & 5499 & 0.467 & 0.499 & 0 & 1 \\
\hline Size of the place currently live in & 5499 & 4.160 & 1.607 & 1 & 9 \\
\hline Live with a partner & 5499 & 0.411 & 0.492 & 0 & 1 \\
\hline Speaks English & 5499 & 0.869 & 0.338 & 0 & 1 \\
\hline Has secondary education & 5499 & 0.571 & 0.495 & 0 & 1 \\
\hline Father's education & 5160 & 0.399 & 0.490 & 0 & 1 \\
\hline Number of times in unemployment & 5499 & 2.137 & 1.400 & 1 & 5 \\
\hline Eastern European & 5499 & 0.356 & 0.479 & 0 & 1 \\
\hline
\end{tabular}

Source: own computations using MOVE project data

In the case of mobile youth, $35 \%$ of fathers have higher and post-higher education, while the score is $26 \%$ for the non-mobile youth. For both categories, the respondents have already been two times in unemployment by the moment of the interview. Finally, due to sample selection, the geographical distribution is a bit unbalanced: more respondents from western countries are mobile in the sample.

The descriptive statistics on the variables of interest prove that there are differences between the group of mobile and non-mobile youth in education, family background and entrepreneurial interest, while in terms of age and gender the groups are very similar.

We firstly run a base model in which the dependent variable is the quality of the respondent to be an entrepreneur or not. Using a simple logistic regression, we include a dummy for the mobility experience: 1 if the individual had an international mobility, 0 - otherwise. 
The other explanatory variables are the ones presented above. Table no. 2 reports the Odds Ratio, for the simplicity of interpretation. Firstly, we notice that in the case of mobile youth the odds of being an entrepreneur after return are double as compared to non-mobile individuals. Remarkably, this variable has the largest effect in the model. Also the odds are higher for those living with a partner and for Eastern Europeans and lower for men. Human capital (education, the knowledge of foreign languages) does not seem to significantly affect entrepreneurial decision.

Table no. 2: Logistic regression results for "being an entrepreneur".

\begin{tabular}{|c|c|c|c|c|c|c|}
\hline & Odds Ratio & Std Error & $\mathbf{z}$ & $\mathbf{P}>\mathbf{Z}$ & \multicolumn{2}{|c|}{ [95\% Conf. Interval] } \\
\hline Mobile & 2.061357 & 0.282197 & 5.28 & 0.000 & 1.576249 & 2.695762 \\
\hline Age & 1.029072 & 0.023533 & 1.25 & 0.210 & 0.983968 & 1.076245 \\
\hline Male & 0.698434 & 0.093281 & -2.69 & 0.007 & 0.537577 & 0.907423 \\
\hline $\begin{array}{l}\text { Size of the place } \\
\text { currently live in }\end{array}$ & 1.022359 & 0.041813 & 0.54 & 0.589 & 0.943606 & 1.107685 \\
\hline Live with a partner & 1.738823 & 0.240824 & 3.99 & 0.000 & 1.325456 & 2.281106 \\
\hline Speaks English & 0.846711 & 0.159039 & -0.89 & 0.376 & 0.585939 & 1.223538 \\
\hline Has secondary education & 1.038735 & 0.153288 & 0.26 & 0.797 & 0.777842 & 1.387132 \\
\hline Father's education & 0.834024 & 0.120928 & -1.25 & 0.211 & 0.627712 & 1.108147 \\
\hline $\begin{array}{l}\text { Number of times in } \\
\text { unemployment }\end{array}$ & 1.08866 & 0.050374 & 1.84 & 0.066 & 0.994274 & 1.192006 \\
\hline Eastern European & 1.391318 & 0.192694 & 2.38 & 0.017 & 1.060565 & 1.825222 \\
\hline Number of obs $=$ & & & & & & \\
\hline LR $\operatorname{chi} 2(11)=79.16$ & & & & & & \\
\hline Log likelihood $=-952.994$ & & & & & & \\
\hline Prob $>$ chi $2=0.0000$ & & & & & & \\
\hline Pseudo R2 $=0.0400$ & & & & & & \\
\hline
\end{tabular}

Source: own computations using MOVE project data

Firstly, we notice that being mobile is the most relevant factor that explains entrepreneurship, mobile respondents being two times more likely to become entrepreneurs. Secondly, males have a lower propensity of being entrepreneurs. Without paying a special interest to gender differences, the paper confirms a gender gap, as opposite to other previous results that find "the lack of a gender difference in entrepreneurial intention" (Díaz-García and Jiménez-Moreno, 2010). Thirdly, people living with a partner are more likely to be self-employed; finally, the Eastern European young respondents are more likely to become entrepreneurs as compared to the Western ones. Being more inclined towards labor mobility than for other mobility types (Manafi et al., 2017), Eastern Europeans may find it more attractive to go into entrepreneurship after return.

Due to potential endogeneity problems, the estimates of the parametric modelling could be biased. Under these circumstances, a counterfactual strategy based on several matching procedures was applied. In the next stage, we run the PSM analysis following the steps described in Section 2. The propensity score was estimated through pscore command in STATA, which employs a logistic regression model. Table no. 3 shows the results for the logistic regression. 
Table no. 3: Logistic regression results for "being mobile"

\begin{tabular}{|c|c|c|c|c|c|c|}
\hline & Coef. & Std. Err. & $\mathbf{z}$ & $\mathbf{P}>\mathbf{z}$ & \multicolumn{2}{|c|}{$\begin{array}{l}\text { [95\% Conf. } \\
\text { Interval] }\end{array}$} \\
\hline Age & 0.0552 & 0.0102 & 5.43 & 0.000 & 0.0353 & 0.0751 \\
\hline Male & 0.1275 & 0.0601 & 2.12 & 0.034 & 0.0097 & 0.2453 \\
\hline $\begin{array}{l}\text { Size of the place } \\
\text { currently live in }\end{array}$ & 0.0431 & 0.0191 & 2.26 & 0.024 & 0.0057 & 0.0804 \\
\hline Live with a partner & 0.1076 & 0.0631 & 1.71 & 0.088 & -0.0160 & 0.2312 \\
\hline Speaks English & 0.4384 & 0.0949 & 4.62 & 0.000 & 0.2524 & 0.6245 \\
\hline $\begin{array}{ll}\text { Has } & \text { secondary } \\
\text { education } & \\
\end{array}$ & -0.6367 & 0.0652 & -9.76 & 0.000 & -0.7645 & -0.508 \\
\hline Father's education & -0.0933 & 0.0626 & -1.49 & 0.136 & -0.2160 & 0.0294 \\
\hline $\begin{array}{l}\text { Number of times in } \\
\text { unemployment }\end{array}$ & 0.0921 & 0.0214 & 4.29 & 0.000 & 0.0501 & 0.1341 \\
\hline Eastern European & -0.5471 & 0.0661 & -8.28 & 0.000 & -0.6767 & -0.417 \\
\hline Constant & -212 & 0.29095 & -7.29 & 0.000 & 690.94 & -1.550 \\
\hline \multicolumn{2}{|c|}{ Number of obs. } & 5160 & & & & \\
\hline LR chi2(9) & $=$ & 357.21 & & & & \\
\hline Prob > chi 2 & $=$ & 0.0000 & & & & \\
\hline Log likelihood & $=$ & -3243.6 & & & & \\
\hline Pseudo R2 & $=$ & 0.0522 & & & & \\
\hline
\end{tabular}

Source: own computations using MOVE project data

The results are highly significant, even if the pseudo $\mathrm{R}^{2}$ is rather modest $(5.22 \%)$ and it is obvious that more variables are needed to overcome unobserved influences on the decision to become mobile. Most of the variables are statistically significant, confirming the adequate variable selection and their relevance for the PSM score generation.

In the second step, different matching methods were used. In all cases the common support option was selected and the common support interval was $(0.1158 ; 0.7853)$, so that the individuals with propensity scores outside the common support region were excluded from the matching procedures. Table no. 4 synthetizes the results and also presents the effect of being mobile on the propensity to become entrepreneur. It is noticeable that the applied matching methods produced very similar results: the ATT connotes the individuals with previous international mobility experience have a higher propensity to become entrepreneurs, compared to the persons without a mobility experience (Table no. 4)

Table no. 4: Average treatment on treated (ATT) group

\begin{tabular}{|l|c|c|r|r|r|}
\hline \multicolumn{1}{|c|}{ Matching methods } & $\begin{array}{c}\text { No. } \\
\text { treat. }\end{array}$ & $\begin{array}{c}\text { No. } \\
\text { contr. }\end{array}$ & \multicolumn{1}{c|}{ ATT } & \multicolumn{1}{c|}{ Std. Err. } & \multicolumn{1}{c|}{ t } \\
\hline Nearest Neighbor & 1952 & 1581 & $\mathbf{0 . 0 3 8}$ & 0.008 & 4.668 \\
\hline Stratification method & 1952 & 3200 & $\mathbf{0 . 0 3 6}$ & 0.007 & 5.124 \\
\hline Radius method & 1952 & 3200 & $\mathbf{0 . 0 3 5}$ & 0.007 & 5.300 \\
\hline Kernel method & 1952 & 3200 & $\mathbf{0 . 0 3 6}$ & & \\
\hline
\end{tabular}

Source: own computations using MOVE project data

Our results confirm that the mobility experience has a strong positive impact on becoming an entrepreneur. The internationally mobile respondents have an increased probability by 
3.5 to 3.8 p.p. of becoming an entrepreneur after return, comparable to non-mobile youth. The value may seem modest, but when looking closer to the results, it is reported that post matching mobile youth have a propensity of becoming entrepreneurs of 7.06 p.p., which is more than double compared to non-mobile youth (3.26 p.p.). Therefore, being internationally mobile in Europe has a significant positive impact on becoming an entrepreneur or freelancer after return in the country of origin. Wahba and Zenou (2012) find similar results referring to adult migrants in Egypt.

This result contributes to the literature on the determinants of entrepreneurship and provide a possible answer to the question what makes a young entrepreneur? Being mobile has beneficial effects at least for the case of European youth and it is a significant factor in the constellation of numerous potential factors contributing to entrepreneurial initiatives.

\section{Conclusions}

The aim of this paper is to showcase the impact of mobility on the propensity of becoming an entrepreneur in the cases of European youth, particularly after their return to their home country. Our results indicate that the experience of mobility inside the European space has a positive impact on entrepreneurship, which could lead to the attenuation of youth unemployment as well as to a sustainable economic development for the home countries. A potential limit of the research regards the limited number of variables used in computing the PSM scores, the results being however statically significant. The dataset that was used had been collected in 2017. The approach of the authors can be considered quasiexperimental, as it uses various matching procedures on a propensity score matching technique. It has been remarked that individuals who have been mobile have a propensity of being an entrepreneur higher by 3.5 to 3.8 percentage points than those who have not been mobile.

Also, being mobile is more likely to happen for people speaking the English language and for those with a larger number of unemployment stages. Being mobile is slightly less likely for males and also for Eastern Europeans.

These results confirm that one of the beneficial effects of intra-European mobility is increasing the propensity for entrepreneurship that positively impacts the labor market outcomes. They are supported by the results from qualitative analysis emerged from MOVE project and worth mentioning that Romanian international volunteers became entrepreneurs after return, using their personal development through intercultural exchange for economic purposes (Roman et al., 2019)

Moreover, the high international interest in increasing entrepreneurship among young generation is supported by a number of European programs, such as ERASMUS+ (DabasiHalász et al., 2019). The result of this research supports an integrated policy approach for increasing both mobility and entrepreneurship in the case of young people. However, it seems obvious that the small youth self- employment and youth mobility rates in Europe suggest that the existing programs could and should be improved. Therefore, this creates the room for future research in the field from a both theoretical and an applied perspective. 


\section{Acknowledgements}

The paper is a result of the MOVE project, „Mapping mobility - pathways, institutions and structural effects of youth mobility in Europe". MOVE has received funding from the European Union's Horizon 2020 research and innovation programme under grant agreement No 649263. Parts of the results were presented at the BASIQ Conference 2019. The authors thank participants for comments and useful suggestions.

\section{References}

Acs, Z.J., Desai, S. and Hessels, J., 2008. Entrepreneurship, economic development and institutions. Small business economics, 31(3), pp. 219-234.

Baycan-Levent, T. and Nijkamp, P., 2009. Characteristics of migrant entrepreneurship in Europe. Entrepreneurship and regional development, 21(4), pp.375-397.

Becker, S.O. and Ichino, A., 2002. Estimation of average treatment effects based on propensity scores. The Stata Journal, 2(4), pp. 358-377.

Brzozowski, J., Cucculelli, M. and Surdej, A., 2017. The determinants of transnational entrepreneurship and transnational ties' dynamics among immigrant entrepreneurs in ICT sector in Italy. International Migration, 55(3), pp.105-125.

Caliendo, M. and Kopeinig, S., 2008. Some practical guidance for the implementation of propensity score matching. Journal of Economic Surveys, 22(1), p. 3172.

Chigunta, F.J., 2002. Youth entrepreneurship: Meeting the key policy challenges Education. [online] Available at: <https://www.academia.edu/25132959/Youth Entrepreneurship_Key_Challenges_for_Inclusive_Development $>$ [Accessed 3 March 2019].

Constant, A. F., Nottmeyer, O. and Zimmermann, K. F., 2013. The economics of circular migration. International handbook on the economics of migration. Cheltenham: Edward Elgar, pp. 55-74.

Cuervo, A., 2005. Individual and environmental determinants of entrepreneurship. The International Entrepreneurship and Management Journal, 1(3), pp. 293-311.

Dabasi-Halász, Z., Kiss, J., Manafi, I., Marinescu, D.E., Lipták, K., Roman, M. and Lorenzo-Rodriguez, J., 2018. International youth mobility in Eastern and Western Europe-the case of the Erasmus+ programme. Migration Letters, 16(1), pp.61-72.

Dehejia, R.H. and Wahba, S., 2002. Propensity score matching methods for nonexperimental causal studies. Columbia University Discussion Paper Series, Discussion Paper \#:0102-14.

Díaz-García, M.C. and Jiménez-Moreno, J., 2010. Entrepreneurial intention: the role of gender. International Entrepreneurship and Management Journal, 6(3), pp.261-283.

Dvouletý, O., 2017. Determinants of Nordic entrepreneurship. Journal of Small Business and Enterprise Development, 24(1), pp.12-33.

Eurostat, 2019. Eurostat database. [online] Available at: <https://appsso.eurostat.ec. europa.eu/nui/show.do?dataset=yth_empl_040\&lang=en> [Accessed 3 September 2019].

Grilo, I. and Thurik, R., 2014. Determinants of Entrepreneurship in Europe. ERIM Report Series. Reference No. ERS-2004-106-ORG. <online> Available at: <https://ssrn.com/ abstract $=636815>$ [Accessed 3 September 2019]. 
Hamdouch, B. and Wahba, J., 2015. Return migration and entrepreneurship in Morocco. Middle East Development Journal, 7(2), pp.129-148.

Hemming, K., Schlimbach, T., Tillmann, F., Nienaber, B., Roman, M. and Skrobanek, J., 2018. Structural framework conditions and individual motivations for youth-mobility: A macro-micro level approach for different European country-types. Migration Letters, 16(1), pp. 45-59.

Kardos, M., 2012. The Relationship between entrepreneurship, innovation and sustainable development. Research on European Union Countries. Procedia Economics and Finance, 1(3), pp. 1030-1035.

Kojo Oseifuah, E., 2010. Financial literacy and youth entrepreneurship in South Africa. African Journal of Economic and Management Studies, 1(2), pp.164-182.

Krisciunas, K. and Greblikaite, J., 2007. Entrepreneurship in Sustainable Development: SMEs Innovativeness in Lithuania. Engineering Economics, 4(54), pp. 20-26.

Liñán, F. and Fayolle, A., 2015. A systematic literature review on entrepreneurial intentions: citation, thematic analyses, and research agenda. International Entrepreneurship and Management Journal, 11(4), pp.907-933.

Lofstrom, M. and Wang, C., 2019. Immigrants and entrepreneurship. IZA World of Labor. [online] Available at: < https://wol.iza.org/articles/immigrants-and-entrepreneurship> [Accessed 25 September 2019].

Manafi, I., Marinescu, D., Roman, M., and Hemming, K., 2017. Mobility in Europe: Recent trends from a cluster analysis. Amfiteatru Economic, 19(46), pp. 711-727.

Nabi, G. and Liñán, F., 2011. Graduate entrepreneurship in the developing world: intentions, education and development. Education+training, 53(5), pp. 325-33.

Naudé, W., Siegel, M. and Marchand, K., 2017. Migration, entrepreneurship and development: critical questions. IZA Journal of Migration, 6(5), pp. 1-30.

Navarrete Moreno, L., Lorenzo-Rodríguez, J., Díaz Chorne, L., Díaz Catalán, C., SuárezLledó, V.S., Fernández Araiz, V., García Cuenca, C., Pallarés I Cardona, E., Zúñiga, R., de Luxán, A., Skrobanek, J., Kmiotek-Meier, E., Hemming, K., Tillman, F., Manafi, I. and Marinescu, D., 2017. MOVE Deliverable D.4.7 - Public Work Package 4 Report. [online] Available at: <http://move-project.eu/reports-publications/> [Accessed 3 March 2019].

Nikolaev, B.N., Boudreaux, C.J. and Palich, L., 2018. Cross- country determinants of early- stage necessity and opportunity- motivated entrepreneurship: accounting for model uncertainty. Journal of Small Business Management, 56, pp. 243-280.

OECD, 2001. Putting the Young in Business: Policy Challenges for Youth Entrepreneurship. [online] Paris: The LEED Programme, Territorial Development Division. Available at: <http://www.oecd.org/cfe/leed/putting\%20the\%20young\% 20to\%20businesspdf.pdf> [Accessed 2 March 2019].

OECD/European Union, 2017. Self-employment and entrepreneurship by the unemployed, in The Missing Entrepreneurs 2017: Policies for Inclusive Entrepreneurship. [online] Paris: OECD Publishing. Available at: <https://www.oecd-ilibrary.org/docserver/ 9789264283602-10-en.pdf?expires $=1568782199 \&$ id=id\&accname $=$ guest $\&$ checksum $=$ 0CFDD89EB70515037E9870AABA618F5B> [Accessed 12 September 2019]. 
Ojiaku, O.C., Nkamnebe, A.D. and Nwaizugbo, I.C., 2018. Determinants of entrepreneurial intentions among young graduates: perspectives of push-pull-mooring model. Journal of Global Entrepreneurship Research, 8(1), pp. 24.

Popescu, C., Bostan, I., Robu, I.B. and Maxim, A., 2016. An analysis of the determinants of entrepreneurial intentions among students: A Romanian case study. Sustainability, 8(8), p.771.

Popescu, M.E. and Roman, M., 2018. Vocational training and employability: Evaluation evidence from Romania. Evaluation and program planning, 67, pp. 38-46.

Reynolds, P., Bosma, N., Autio, E., Hunt, S., De Bono, N., Servais, I., Lopez-Garcia, P. and Chin, N., 2005. Global entrepreneurship monitor: Data collection design and implementation 1998-2003. Small business economics, 24(3), pp.205-231.

Roman, M. and Goschin, Z., 2012. Romanian Immigrants Worldwide: What makes them Return Home?. Journal of Identity and Migration Studies, 6(2), pp. 2-20.

Roman, M., Muresan, L.M., Manafi, I. and Marinescu, D., 2019. Volunteering as international mobility: Recent evidence from a post-socialist country. Transnational Social Review, 8(3), pp. 258-272.

Roman, M., 2019. Work and welfare take-up of enlargement migrants in the United Kingdom. Applied Economics Letters, 26(5), pp. 341-344.

Roman, M. and Paraschiv, D.M., 2019. Does intra-European mobility impact youth entrepreneurship? In: The Association for Innovation and Quality in Sustainable Business - BASIQ, University of Bari Aldo Moro, Bucharest University of Economic Studies, Amfiteatru Economic, The BASIQ 2019 Conference, New trends in sustainable business and consumption. Bari, Italy. 30 May - 1 June 2019. Bucharest: ASE.

Rosenbaum, P. and Rubin, D., 1983. The Central Role of the Propensity Score in Observational Studies for Causal Effects. Biometrika, 70(1), pp. 41-55.

Szarucki, M., Brzozowski, J. and Stankevičienè, J., 2016. Determinants of self-employment among Polish and Romanian immigrants in Germany. Journal of Business Economics and Management, 17(4), pp. 598-612.

Virgill, N. A., 2009. Export Processing Zones: Tools of Development or Reform Delay? (Doctoral dissertation). [online] Available at: <http://ebot.gmu.edu/ bitstream/handle/ 1920/4509/Virgill_Nicola.pdf?sequence=1\&isAllowed=y> [Accessed 2 March 2019].

Wahba, J. and Zenou, Y., 2012. Out of sight, out of mind: migration, entrepreneurship and social capital. Regional Science and Urban Economies, 42(5) pp. 890-903.

Wahba, J., 2015. Selection, selection, selection: the impact of return migration. Journal of Population Economics, 28(3), pp. 535-563.

Weinberger, K.Q. and Saul, L.K., 2009. Distance metric learning for large margin nearest neighbor classification. Journal of Machine Learning Research, 10(Feb. iss.), pp.207-244.

Wennekers, S., Van Stel, A., Carree, M. and Thurik, R., 2010. The relationship between entrepreneurship and economic development: is it U-shaped?. Foundations and Trends in Entrepreneurship, 6(3), pp.167-237.

Wordofa, M.G. and Sassi, M., 2014. Improving Smallholder Farmers' Income through Farmer Training Centers: an Impact Evaluation in Haramaya District [online] Available at: <http://economia.unipv.it/naf/> [Accessed 3 March 2019]. 